\title{
Inflation Rate, Exchange Rate, Remittances Inflows and Economic Performance in Nigeria: A Granger Causality
}

\section{Approach}

\author{
Peter Ego Ayunku \\ Niger Delta University, Department of Banking and Finance, \\ Wilberforce Island, Bayelsa State, Nigeria
}

Rachel Konyefa Dickson

Niger Delta University, Department of Management,

Wilberforce Island, Bayelsa State, Nigeria

Received: Jan. 10, 2021 Accepted: Feb. 5, $2021 \quad$ Online published: Feb. 17, 2021

doi:10.5296/ijhrs.v11i1.18310 URL: https://doi.org/10.5296/ijhrs.v11i1.18310

\begin{abstract}
This study empirically investigated the impact of inflation rate, exchange rate and remittances inflows on the economic performance of Nigeria using time series data from 1960 to 2018. The study employed econometric techniques such as the Augmented Dickey Fuller (ADF) unit root test, correlation statistics, granger causality testand the ordinary least squares multivariate regression methods to analyze the data. The study finding showed that remittances inflows are a major driver of economic activities and growth in the Nigeria clime. Exchange rate exerted a positive impact on gross domestic product per capita growth in Nigeria. Both remittances inflows and exchange rate maintained a bi-directional causality with the performance of economy of Nigeria. The study concludes that remittances inflows have a correlation with monetary policy transmission mechanisms towards enhancing the performance of the economy of Nigeria. It is therefore recommended that the government needs to create investors' friendly environment capable of encouraging migrants to channel their resources into the economy. This will help to boost economic activities, reduce unemployment rate, increases savings, with the end goal of engendering economic performance of Nigeria. To reduce the effect of Inflation in Nigeria, this study suggests that the policy monetary authority $(\mathrm{CBN})$ needs to come up with a policy framework that can enhance the country's capital stock instead of expending it.
\end{abstract}


Keywords: remittances inflows, monetary policy, inflation rate, exchange rate, gross domestic product per capita growth

\section{Introduction}

Inflation is an economic condition in which means more money is chasing few items in the market; and it occurs in periods of falling value of money, caused by consistent, persistent and sustained increases in the prices of goods and services. Despite the application of the monetary policy tools, inflation has continued to pose challenges to the monetary authorities. Some of the reasons include the inability of the monetary authorities to enforce compliance through the monetary channel in the banking and non-banking institutions, and fiscal imbalance characterized with expansionary fiscal policy with deficit budget (Ggor, 2011; Umeredu, 2007). In the developed economies, substantial evidences aboundconcerning the effectiveness of inflation rate and exchange rate on economic growth using cross-sectional, time series data in country - specific, and cross-country basis (Srithitat\& Sun, 2017; Iheanacho, 2019). The correlation between remittances inflows and inflation rate and exchange rates as well as their impacts on the performance of an economy on country specific and cross-country basis via a dynamic estimation model lacks empirical evidences from Nigeria.

Fewer consensuses appear to exist about the precise nexus between inflation rate and economic performance (Chimobi, 2010). This has continued to generate a significant debate both theoretically and empirically (Chimobi, 2010). Several studies have reported inconclusive empirical evidence regarding the association between inflation and economic growth (Saaed, 2007). This was corroborated by the empirical research ofChimobi (2010) where the author states that many researches have been conducted on the nexus between inflation rate and economic performance in developing countries. Despite these plethora of studies both for developing and developed countries, the literature on inflation and economic growth in Nigeria is scanty (Chimobi, 2010).

The flow of funds by migrants across border has increased significantly particularly in developing countries, including Nigeria in recent times. According to the Central Bank of Nigeria (2019) report, Nigeria received about $\$ 613$ billion in 2018 and this has made it become one of the top five recipients of remittance inflows globally. The World Bank (2018) records reveal that remittances in the context of Nigeria have been increasing astronomically over the last decade. Remittances by migrants increase the flow of funds from a foreign country to a home country. Remittances are spent partly on consumption and partly on investment. The direct effect of remittances on aggregate demand is because of the increase in consumption expenditure of the receiving households which in turn creates an inflationary pressure. Nisar and Mishra (2013) posit that while remittances inflows encourage other development aid (ODA), enhances stock of money in an economy, it is however inflation inducing given the appreciation or depreciation of the exchange rate for a period. In the view of Balderas and Nath (2008), Narayan and Mishra (2011), Khan and Islam (2013) remittance inflows are capable of inducing inflation in recipient economies.

Methodologically, researches which have examined monetary policy fail to assess the 
implication of remittances inflowswth inflation rate and exchange rate on the economic performance of developed and developing countries through the instrumentality of the ordinary least squares regression method; hence this study is undertaken with a view to bridging the gap. Apart from the introductory section; section two dwells on literature review; section three concentrates on the methodology of the study; section four is on the empirical analysis; while section five is conclusion and recommendations.

\section{Literature Review}

\section{Empirical Review}

Ogbeide and Olabisi (2020) investigated carried out an empirical of the impact of remittance inflows on inflation in Nigeria. The result of the pairwise Granger causality test showed no causality between remittance inflows and inflation in Nigeria. The bound test result indicates a long-run co-integration among the variables estimated in the study.Ball, Lopez and Reyes (2013) used a theoretical model and panel vector auto-regression techniques to test the same effect using yearly as well as quarterly data for 21 emerging countries. Their theoretical model predicts that remittances temporarily increase domestic money supply and inflation under a fixed exchange rate regime while it temporarily generate no change in the money supply, it decreases inflation and appreciate the real exchange rate under a flexible exchange rate regime. However, Reinhart and Rogoff (2004) show that, the resulting effect of remittance inflows will be a rising price level and an appreciation of the exchange rate under a flexible exchange rate regime. Nisar and Tufail (2013) examined the impact of remittances on inflation, food inflation, footwear and textile, housing and construction inflation for Pakistan by using Johansen and Juselius (1990) co-integration technique over the time period, 1970-2010. The study found that remittances have positive impact on inflation. Khan and Islam (2013) verified how remittances inflows affect the inflation rate in Bangladesh for the 1972-2010 time period by applying vector autoregressive (VAR) techniques. Their empirical results conclude that a one percent increase in remittance inflows lead to a rise in inflation by 2.48 percent in the long run, whereas no significant relationship is evident between these two variables in the short-run.

Afolabi, Belford, Yemisi and Ehinomen (2016) examined the nexus between exchange rates and economic growth in Nigeria over the period of 1978 to 2014. The study analyzed the data using ordinary least square (OLS) method. The finding shows that exchange rates positively and significantly influence economic growth and vice versa. The short-run directional relations were established between the exchange rates and economic growth in the country via Pairwise granger causality tests. The study concludes that exchange rates and economic growth influenced by one another.

Chen (2012) researched on real exchange rate and economic growth with evidence from Chinese provincial data in the period, 1992 to2008. The results reported here confirm the positive effect of real exchange rate appreciation on economic growth in the provinces. Mbutor (2010) examined the role of monetary policy in enhancing remittances for economic growth in Nigeria. Vector autoregressive method with two stage deductions were applied on the data analysis. The study finding indicates that monetary policy rate first impacts 
intervening variables such as exchange rate, interest rate, inflation which in turn impact on remittance inflows. The study also showed that domestic economic performance increases remittances to Nigeria, while exchange rate depreciation depresses remittances. The study concluded that remittance inflows in an economy are an indication of stronger naira, which reflects a sign of things - setting - better back home.

Ahmed and Mortaza (2005) empirically explored the relationship between inflation and economic growth in Bangladesh, using annual data set on real GDP and CPI for the period of 1980 to 2005, and the co-integration and error correction models. The empirical evidence demonstrates that there exists a statistically significant long-run negative relationship between inflation and economic growth for the country as indicated by a statistically significant long-run negative relationship between CPI and real GDP. Chimobi (2010) determine the relationship between Inflation and economic performance in Nigeria between 1970 and 2005. Consumer price index (CPI) was used as a proxy for inflation and the GDP as a perfect proxy for economic performance. The research used Johansson co-integration technique and Granger causality test top analyze the data. The result no co-integrating relationship between Inflation and economic performance of Nigeria in the period. Unidirectional causality was observed running from Inflation to economic performance.

Srithilat and Sun (2017) investigated the impact of monetary policy on economic development in Lao PDR using time series data from 1989 to 2016. They employed Johansen co-integration and error correction model. The study finding indicates that inflation rate exerted a negative effect on the real GDP per capita in the long - run. Alavinasab (2016) studied the impact of monetary policy on economic growth in Iran - Error correction model was employed to analyse the time series data in the period by the author. The empirical finding reveals that inflation maintained a significant positive association with economic growth in Iran. Nibeza (2015) employed Johansen co-integration technique and error correction model to determine the long - run and short - run relationship of inflation rate in Rwanda. The result of the empirical analysis shows that inflation rate distorts the economic performance of the country.It can be observed that the prior studies reviewed above failed to examine the association between inflation rate, exchange rate and remittances on the economic performance of Nigeria. This constitutes a research gap this study seeks to fill on the empirical fronts.

\section{Methodology}

The study used the causal-effect and correlation research designs. The time series data for the period, 1960 to 2018 were generated from secondary sources which include from the Central Bank of Nigeria Statistical Bulletin (various issues) and the World Bank Indicators (various issues). This represents about fifty eight annual observations. Time series data on the relevant variables such as Gross Domestic Product (GDP) per capita, a proxy for economic performance; migrant remittances inflows, inflation rate and exchange were used. The study employs Augmented and Dickey Fuller unit root test, correlation statistics, Engle and Granger Causality test and dynamic estimation methods to analyze the time series data generated. The mathematical form of the model variables of the model in this study are stated as follow: 


$$
G D P P C_{t}=f\left(R E M I T R_{t}, I N F R_{t} \text { and } E X R_{t}\right)
$$

This is further stated in a stochastic dynamic model as follow:

\section{Ordinary Least Square Multivariate Regression Estimation Model}

$$
\begin{aligned}
\triangle G D P P C t= & \beta_{0}+\beta_{1} \text { REMITR }_{t}+\beta_{2} \text { EXR }_{t}+\beta_{3} I N F R_{t} \\
& +\mu_{t} \ldots \ldots \ldots \ldots \ldots \ldots \ldots \ldots \ldots \ldots \ldots \ldots \ldots \ldots \ldots
\end{aligned}
$$

Where; GDPPCG represents gross domestic product per capital; REMITR is migrant remittance inflows, INFR represents inflation rate, EXR is nominal exchange rate.

\section{EMPIRICAL ANALYSIS}

This subsection entails the presentation of the unit root tests, correlation and dynamic estimation results. The empirical results are presented sequentially as follows:

\section{Unit Root Test Result}

A standard practice in economic test of macroeconomic data analysis begins with the test of stationarity of variables using the appropriate unit root test procedures. This study employs the Augmented Dickey-Fuller (ADF) test to perform the unit root test in all the series of the model and examine their order of integration. The results of the ADF unit root test statistics in both level and first difference are presented in table1 below:

Table 1. Shows the ADF statistics unit root tests

\begin{tabular}{|c|c|c|c|c|}
\hline \multirow{3}{*}{ Variables } & \multicolumn{2}{|c|}{$\begin{array}{c}\text { ADF Test Statistics at } \\
\text { Level }\end{array}$} & \multicolumn{2}{c|}{$\begin{array}{c}\text { ADF Test Statistics at } 1^{\text {st }} \\
\text { Difference }\end{array}$} \\
\cline { 2 - 5 } & $t$-ADF & $P$-value & $t$-ADF & $P$-value \\
\hline GDPPCG & -4.704122 & $0.0003^{*}$ & - & - \\
\hline REMITR & - & - & -3.146863 & $0.0292^{*}$ \\
\hline INFR & - & & -5.971552 & $0.0000^{*}$ \\
\hline \multirow{2}{*}{ EXR } & & & -4.919846 & 0.0001 \\
\hline
\end{tabular}

\section{Source: Authors' compilation from E-views 8.0}

At 5 per cent significance level, the results of the ADF unit-root tests provide very strong evidence of stationarity at level for gross domestic product per capita growth. But at first difference, remittances inflows, inflation rate and exchange rate displayed stationarity results which implied that the three series were integrated at order one. The test result indicates absence of spuriousness in the time series.

\section{Correlation Statistics}

Table 2. Correlation Matrix Result 


\begin{tabular}{|c|c|c|c|c|}
\hline $\begin{array}{c}\text { VARIABLE } \\
\text { S }\end{array}$ & GDPPCG & REMITR & INFR & EXR \\
\hline GDPPCG & 1 & & & \\
\hline REMITR & 0.01556 & 1 & & \\
\hline INFR & -0.1247 & -0.0009 & 1 & \\
\hline EXR & 0.0685 & 0.9181 & -0.1100 & 1 \\
\hline
\end{tabular}

Source: Authors' Computation from E-views 8.0

Table 2 result indicates that gross domestic product per capita growth (GDPPCG) and remittance inflows (REMITR) are positively correlated $(r=0.01556)$. The result suggests that migrant remittance is a key driver of the economic performance of Nigeria. The finding is in tandem with Gross domestic product per capita growth and inflation rate (INFR) are negatively correlated ( $r=-0.1247)$. The result is an indication that inflation reduces the economic performance of Nigeria. The finding is in consonance with the researches of Saaed (2007); Chimobi (2010). Gross domestic product per capital growth (GDPPCG) and exchange rate are positively correlated $(r=0.0685)$ in the reference period. The result agrees with Afolabi et al. (2016). In the same vein, inflation rate is negatively correlated with remittance inflows $(r=-0.1100)$.

Table 3. Ordinary Least Square Multivariate Regression Result

Dependent Variable: GDPPCG

Method: Least Squares

Date: 09/12/20 Time: 10:39

Sample (adjusted): 19612018

Included observations: 56 after adjustments

Convergence achieved after 7 iterations

\begin{tabular}{|c|c|c|c|c|}
\hline Variable & Coefficient & Std. Error & t-Statistic & Prob. \\
\hline $\mathrm{C}$ & 2.136217 & 2.292989 & 0.931630 & 0.355 \\
\hline REMITR & 2.289418 & 3.212333 & -0.712696 & 0.0003 \\
\hline INFR & -0.062754 & 0.068530 & -0.915714 & 0.0041 \\
\hline EXR & 0.036880 & 0.041841 & 0.881417 & 0.0022 \\
\hline $\operatorname{AR}(1)$ & 0.435419 & 0.125758 & 3.462346 & 0.0011 \\
\hline & \multicolumn{4}{|c|}{ Mean dependent } \\
\hline R-squared & \multicolumn{3}{|c|}{$\begin{array}{l}0.714237 \mathrm{var} \\
0.652609 \text { S.D denendent var }\end{array}$} & \multirow{2}{*}{$\begin{array}{l}0.986775 \\
6.951634\end{array}$} \\
\hline Adjusted R-squared & 0.652609 & \multicolumn{2}{|c|}{$\begin{array}{l}\text { S.D. dependent var } \\
\text { Akaike info }\end{array}$} & \\
\hline S.E. of regression & \multicolumn{3}{|c|}{6.399248 criterion } & 6.635283 \\
\hline Sum squared resid & 2088.469 & \multicolumn{2}{|c|}{$\begin{array}{l}\text { Schwarz criterion } \\
\text { Hannan-Quinn }\end{array}$} & 6.816118 \\
\hline Log likelihood & \multicolumn{3}{|c|}{-180.7879 criter. } & 6.705393 \\
\hline F-statistic & 3.476268 & \multirow{2}{*}{\multicolumn{2}{|c|}{ Durbin-Watson stat }} & 1.836336 \\
\hline Prob(F-statistic) & 0.013816 & & & \\
\hline Inverted AR Roots & .44 & & & \\
\hline
\end{tabular}

From table 3 , it can be observed that the coefficient of the individual explanatory variables 
shows that remittance inflow (REMITR) is positively signed (2.289) and statistically significant at 5\% level ongross domestic product per capita, a proxy of economic performance of Nigeria. The result implies that remittance inflows are a major driver of economic activities and growth in the Nigeria clime. The result is in tandem with Ball, Lopez and Reyes (2013); Khan and Islam (2013); Adigun and Ologunwa (2017).

Inflation rate is negative (-0.062) and statistically significant at 5\% level. It is an indication that high level of inflation rate distorts the performance of economy in Nigeria. This distortionary effect is one of the reasons the monetary authority in Nigeria always seeks to influence the economy through effective monetary policy, which aim is targeted at reducing inflation rate as much as possible. While empirical result is in consonance with Nibeza (2015)' it is however contrary to the research outcome of Alavinasab (2016) which revealed that inflation maintained a significant positive association with economic growth in Iran. Exchange rate is positive (0.036) and statistically significant on the economic performance of Nigeria in the reference period. The result may not be unconnected with the several exchange rate deregulation policy maintained over time by the Federal government of Nigeria, via the Central Bank of Nigeria (CBN). The empirical finding is in line with the research outcome of Chen (2012), Afolabietal. (2016). Adjusted r-squared value of 0.652 , portrays that the independent variables accounted for about $65 \%$ impacts on the performance of the economy of Nigeria. The Durbin-Watson statistics value of 1.836 connotes absence of serial auto correlation in the regression result. This makes the empirical finding very useful for policy implication by concerned regulatory agency and the Federal government of Nigeria.

Table 4. Pairwise Granger Causality Test Result

\begin{tabular}{|c|c|c|c|}
\hline $\begin{array}{l}\text { Pairwise Granger Causality Tests } \\
\text { Date: 09/10/20 Time: 20:11 } \\
\text { Sample: } 19602018 \\
\text { Lags: } 2\end{array}$ & & & \\
\hline Null Hypothesis: & Obs & F-Statistic & Prob. \\
\hline $\begin{array}{l}\text { REMITR does not Granger Cause } \\
\text { GDPPCG } \\
\text { GDPPCG does not Granger Cause REMITR }\end{array}$ & 57 & $\begin{array}{l}0.24157 \\
0.15736\end{array}$ & $\begin{array}{l}0.7003 \\
0.0040\end{array}$ \\
\hline $\begin{array}{l}\text { INFR does not Granger Cause GDPPCG } \\
\text { GDPPCG does not Granger Cause INFR }\end{array}$ & 54 & $\begin{array}{l}0.75160 \\
0.30886\end{array}$ & $\begin{array}{l}0.0000 \\
0.0050\end{array}$ \\
\hline $\begin{array}{l}\text { EXR does not Granger Cause GDPPCG } \\
\text { GDPPCG does not Granger Cause EXR }\end{array}$ & 57 & $\begin{array}{l}0.28450 \\
0.07487\end{array}$ & $\begin{array}{l}0.0006 \\
0.0000\end{array}$ \\
\hline $\begin{array}{l}\text { INFR does not Granger Cause REMITR } \\
\text { REMITR does not Granger Cause INFR }\end{array}$ & 54 & $\begin{array}{l}0.66742 \\
1.19441\end{array}$ & $\begin{array}{l}0.0001 \\
0.0005\end{array}$ \\
\hline $\begin{array}{l}\text { EXR does not Granger Cause REMITR } \\
\text { REMITR does not Granger Cause EXR }\end{array}$ & 57 & $\begin{array}{l}2.33743 \\
3.54907\end{array}$ & $\begin{array}{l}0.0001 \\
0.0359\end{array}$ \\
\hline $\begin{array}{l}\text { EXR does not Granger Cause INFR } \\
\text { INFR does not Granger Cause EXR }\end{array}$ & 54 & $\begin{array}{l}0.28418 \\
0.67349\end{array}$ & $\begin{array}{l}0.7539 \\
0.5146\end{array}$ \\
\hline
\end{tabular}


Source: Authors' Computation from E-views 8.0

Table 4 analysis shows that bi-directional causality between remittances inflows and economic performance of Nigeria. It is a pointer that Migrant remittances inflows boost economic activities in migrants' home country if judiciously invested. The finding is contrary to Ogbeide and Olabisi (2020). Exchange rate and gross domestic product have a-two way causal relationship. This affirms the research finding of Afolabi et al. (2016). Inflation rate and remittances inflows granger causes each other, suggesting that remittances inflows in Nigeria may be inflation inducing. The result is quite contrary to expectation in a study like this. The research outcome is however contrary to the research outcome of Ogbeide and Olabisi (2020). There is a bi-directional causality between exchange rate and remittances inflows. Theoretically, in a period of exchange rate appreciation in a home country's economy, migrants' remittances could be very beneficial in terms of enhancing unearned income levels, consumption and investment capacity.

\section{Conclusion and Recommendations}

The study has examined the nexus between inflation rates, exchange rate and remittances inflows towards the performance of the economy of Nigeria. The study finding showed that remittances inflows are a major driver of economic activities and growth in the Nigeria clime. Remittance inflows when channeled into economic activities tend to boost the performance of the economy of Nigeria, assuming all factors are held constant. Inflation rate contributed negatively to the performance of the economy of Nigeria in the reference period. Exchange rate exerted a positive impact with gross domestic product per capita growth in Nigeria. Both remittances inflows and exchange rate maintained a bi-directional causality with the performance of economy of Nigeria. The study concludes that remittances inflows have a correlation with monetary policy transmission mechanisms towards enhancing the performance of the economy of Nigeria. It is therefore recommended that the government needs to create investors' friendly environment capable of encouraging migrants to channel their resources into the economy. This will help to boost economic activities, reduce unemployment rate, increases savings, with the end goal of engendering economic performance of Nigeria. To mitigate the effect of Inflation in Nigeria, this study suggests that the policy monetary authority $(\mathrm{CBN})$ needs to come up with a policy framework that can increase the country's capital stock instead of expending it.

\section{References}

Adigun, A. O., \& Ologunwa, O. P. (2017). Remittances and economic growth in Nigeria. International Journal of Research in Management, 7(6), 29-41.

Afolabi, B., Belford, A. U., Yemisi, E. K., \& Ehinomen, C. (2016). Exchange rate and economic growth: The Nigerian experience. International Research Journal of Finance and Economics, 153, 85-94.

Ahmed, S., \& Mortaza, G. (2005). Inflation and economigrowth in Bangladesh, Policy Analysis Unit (PAU), Working Paper 0604 
Alvinasab, S. M. (2016). Monetary policy and economic growth.International Journal of Economics, Commerce and Management. Retrieved from http://ijecm.co.uk/wpcontent/uploads/2016/03/4315.pdf

Babatunde, M. A., \& Shuaibu, I. M. (2011).Money supply, inflation and economic development in Nigeria.Assia-African Journal of Economics and Econometrics, 11(1), 147-163.

Balderas, T., \& Nath, K. (2008).A Vector error correction and non nested modeling of money demand function in Nigeria. Economics Bulletin, 3, 1-8.

Ball, C., Lopez, C., \& Reyes, J. (2012). Remittances, inflation and exchange rate regimes in Small open Economies. MPRA Paper No. 39852, University Library of Munich, Germany.

Central Bank of Nigeria, (2019). Determination of inflation threshold for Nigeria, a paper presented at the MPC workshop, October 2013.

Chimobi, O. P. (2010). Inflation and economic growth in Nigeria. Journal of Sustainable Development, 3(2), 159-166. https://doi.org/10.5539/jsd.v3n2p159

Ggor, M. L. (2011). The global monetary shocks and inflation in developing economy.International of Economic Management, 41(26), 186-217.

Iheanacho, O. I. (2019). Does inflation weaken economic development? Evidence from Nigeria.European Journal of Accounting Auditing and Finance Research, 1(4), 139-150.

Ishioro, B. O. (2013). Monetary transmission mechanism in Nigeria: A causality test. Mediterranean Journal of Social Sciences, 4(13), 377-388.

Kapur, M. (2004). Exchange rates and monetary policy: The Indian experience, paper presented at the BIS Autumn Economists' Meeting, 28-29 October, Basel.

Khan, Z. S., \& Islam, S. (2013). The effects of remittances on inflation: Evidence from Bangladesh. Journal of Economics and Business Research, 19(2), 198-208.

Mishkin, F. (2007).The Economics of Money, Banking, and Financial Markets. $8^{\text {th }}$ edition. Pearson education international, USA.

Nrarayan, K. L., \& Mishra, P (2011). Monetary policy transmission in emerging market economies: What is new?' BIS Papers, no 35, Bank for International Settlements.

Olabisi, E. O., \& Ogbeide, S. O. (2020). Financial development, remittances inflows and economic growth in Nigeria: A time series analysis. South Asian Journal of Social Studies and Economics, 7(4), 37-43. https://doi.org/10.9734/sajsse/2020/v7i430198

Onouorah, C. A., Shaib, B. A., \& Ehikioya, I. P. (2011). Long run relationship between private investment and monetary policy in Nigeria. Research Journal of Finance and Accounting, 2(6).

Onyeiwu, C. (2012). Monetary policy and economic growth of Nigeria. Journal of Economics and Sustainable development, 3(7), 62-70. 


\section{Macrothink}

International Journal of Human Resource Studies

ISSN 2162-3058 2021, Vol. 11, No. 1

Saaed, A. A. (2007). Inflation and economic growth in Kuwait: 1985-2005-Evidence from co-integration and error correction model. Applied Econometrics and International Development, $7(1)$.

Srithilat, K., \& Sun, G. (2017). The impact of monetary policy on economic development: evidence from Lao PDR. Munich Personal RePEc Archive. MPRA Paper No. 79369. http://mpra.ub.uni-muenchen.de/79369.

Umeredu, C. (2007). Liquidity shocks and asset price boom/bust circles. ECB Working Paper, 732.

World Bank (2018).The World Bank migration and remittances data.Retrieved from bilateral remittance matrix. https://doi.org/10.22617/TCS189320

\section{Appendix A}

\section{Estimation Results}

Null Hypothesis: GDPPCG has a unit root

Exogenous: Constant

Lag Length: 0 (Automatic - based on SIC, maxlag=10)

\begin{tabular}{lccc}
\hline \hline & t-Statistic & Prob. ${ }^{*}$ \\
\hline \hline Augmented Dickey-Fuller test statistic & -4.704122 & 0.0003 \\
\hline Test critical values: & 1\% level & -3.548208 & \\
& 5\% level & -2.912631 & \\
& 10\% level & -2.594027 & \\
\hline
\end{tabular}

*MacKinnon (1996) one-sided p-values.

Augmented Dickey-Fuller Test Equation

Dependent Variable: D(GDPPCG)

Method: Least Squares

Date: 09/09/20 Time: 17:47

Sample (adjusted): 19612018

Included observations: 58 after adjustments

\begin{tabular}{|c|c|c|c|c|}
\hline Vari & Coef & Std. Error & tic & Prob. \\
\hline GDPP & & & & $\begin{array}{l}0.0000 \\
0.4259\end{array}$ \\
\hline $\begin{array}{l}\text {-squared } \\
\text { djusted R-squared }\end{array}$ & $\begin{array}{l}0.283234 \mathrm{va} \\
0.270435\end{array}$ & \multicolumn{2}{|r|}{ dependent } & $\begin{array}{r}-0.03138 \\
7.45673\end{array}$ \\
\hline $\begin{array}{l}\text { S.E. of } \\
\text { Sum sc }\end{array}$ & $\begin{array}{l}6.369137 \mathrm{cr} \\
2271.691\end{array}$ & $\begin{array}{c}\text { Akaike } \\
\text { citerion } \\
\text { Schwarz } \\
\text { Hannan- }\end{array}$ & $\begin{array}{l}\text { info } \\
\text { criterion } \\
\text { Ouinn }\end{array}$ & 6.64572 \\
\hline $\begin{array}{l}\text { Log likelihood } \\
\text { F-statistic } \\
\text { Prob(F-statistic) }\end{array}$ & $\begin{array}{l}-188.6657 \mathrm{cr} \\
22.12876 \\
0.000017\end{array}$ & \multicolumn{2}{|c|}{ Durbin-Watson stat } & $\begin{array}{l}6.602355 \\
1.846512\end{array}$ \\
\hline
\end{tabular}

Null Hypothesis: D(REMITR) has a unit root 
Exogenous: Constant

Lag Length: 5 (Automatic - based on SIC, maxlag=10)

\begin{tabular}{llcc}
\hline \hline & t-Statistic & Prob.* \\
\hline \hline Augmented Dickey-Fuller test statistic & -3.146863 & 0.0292 \\
\hline Test critical values: & 1\% level & -3.562669 & \\
& 5\% level & -2.918778 & \\
& 10\% level & -2.597285 & \\
\hline \hline
\end{tabular}

*MacKinnon (1996) one-sided p-values.

Augmented Dickey-Fuller Test Equation

Dependent Variable: D(REMITR,2)

Method: Least Squares

Date: 09/09/20 Time: 18:15

Sample (adjusted): 19672018

Included observations: 52 after adjustments

\begin{tabular}{|c|c|c|c|c|}
\hline Variable & Coefficient & Std. Error & t-Statistic & Prob \\
\hline D(REMITR) & 6 & 3 & -3 . & 0.002 \\
\hline $\mathrm{D}(\operatorname{REMITR}(-1), 2)$ & 0.47 & & & 0.2763 \\
\hline D(REMITR(-2),2) & 0.194831 & 0.353134 & 0.5 & 0.5839 \\
\hline $\mathrm{D}(\operatorname{REMITR}(-3), 2)$ & 0.018478 & 0.282782 & 0.06 & 0.9482 \\
\hline $\mathrm{D}(\operatorname{REMITR}(-4), 2)$ & -0.232386 & 0.193654 & -1.2 & 0.236 \\
\hline D(REMITR(- & -0.2 & 0.123396 & -1.7 & 835 \\
\hline $\mathrm{C}$ & -0. & 0.040804 & -1 & 36 \\
\hline & & \multicolumn{3}{|c|}{ Mean dependent } \\
\hline R-sc & \multirow{2}{*}{$\begin{array}{l}0.644949 \text { var } \\
0.597609\end{array}$} & & & 478 \\
\hline Adjusted R-s & & Akaike info & S.D. dependent var & 435 \\
\hline S.E. of regre & \multicolumn{3}{|c|}{0.233080 criterion } & 0.049779 \\
\hline Sum squared resid & 2.444682 & \multicolumn{2}{|c|}{$\begin{array}{l}\text { Schwarz criterion } \\
\text { Hannan-Quinn }\end{array}$} & 0.312447 \\
\hline Log likelihood & \multicolumn{3}{|c|}{5.705738 criter. } & 0.150480 \\
\hline F-statistic & 13.62372 & \multirow{2}{*}{\multicolumn{2}{|c|}{ Durbin-Watson stat }} & 2.077697 \\
\hline $\operatorname{Prob}($ F-statistic) & 0.000000 & & & \\
\hline
\end{tabular}

Null Hypothesis: D(INFR) has a unit root 
Exogenous: Constant

Lag Length: 3 (Automatic - based on SIC, maxlag=10)

\begin{tabular}{llcc}
\hline \hline & t-Statistic & Prob.* \\
\hline \hline Augmented Dickey-Fuller test statistic & -5.971552 & 0.0000 \\
\hline Test critical values: & 1\% level & -3.574446 & \\
& 5\% level & -2.923780 & \\
& 10\% level & -2.599925 & \\
\hline \hline
\end{tabular}

*MacKinnon (1996) one-sided p-values.

Augmented Dickey-Fuller Test Equation

Dependent Variable: D(INFR,2)

Method: Least Squares

Date: 09/09/20 Time: 17:48

Sample (adjusted): 19652018

Included observations: 48 after adjustments

\begin{tabular}{|c|c|c|c|c|}
\hline Variable & Coefficient & Std. Error & t-Statistic & Prob. \\
\hline D(INFR(-1)) & -2.042019 & 0.341958 & -5.971552 & 0.0000 \\
\hline $\mathrm{D}(\operatorname{INFR}(-1), 2)$ & 0.998128 & 0.277888 & 3.591839 & 0.0008 \\
\hline $\mathrm{D}(\operatorname{INFR}(-2), 2)$ & 0.440878 & 0.201766 & 2.185100 & 0.0344 \\
\hline $\mathrm{D}(\operatorname{INFR}(-3), 2)$ & 0.369853 & 0.142018 & 2.604263 & 0.0126 \\
\hline \multirow[t]{2}{*}{$\mathrm{C}$} & -0.117469 & 1.884737 & -0.062326 & 0.9506 \\
\hline & \multicolumn{4}{|c|}{ Mean dependent } \\
\hline R-squared & \multicolumn{3}{|c|}{0.639825 var } & 0.032731 \\
\hline Adjusted R-squared & 0.606320 & \multicolumn{2}{|c|}{ S.D. dependent var } & \multirow[t]{2}{*}{20.80011} \\
\hline & & \multicolumn{2}{|c|}{ Akaike info } & \\
\hline S.E. of regression & \multicolumn{3}{|c|}{13.05080 criterion } & \multirow{3}{*}{$\begin{array}{l}8.073908 \\
8.268825\end{array}$} \\
\hline Sum squared resid & 7323.905 & \multirow{2}{*}{\multicolumn{2}{|c|}{$\begin{array}{l}\text { Schwarz criterion } \\
\text { Hannan-Quinn }\end{array}$}} & \\
\hline & & & & \\
\hline Log likelihood & $-188.7738 c$ & \multicolumn{2}{|l|}{ ter. } & 8.147568 \\
\hline F-statistic & 19.09661 & \multirow{2}{*}{\multicolumn{2}{|c|}{ Durbin-Watson stat }} & 2.029853 \\
\hline Prob(F-statistic) & 0.000000 & & & \\
\hline
\end{tabular}

Null Hypothesis: D(EXR) has a unit root 
Exogenous: Constant

Lag Length: 0 (Automatic - based on SIC, maxlag=10)

\begin{tabular}{llcc}
\hline \hline & t-Statistic & Prob.* \\
\hline \hline Augmented Dickey-Fuller test statistic & -4.919846 & 0.0001 \\
\hline Test critical values: & 1\% level & -3.550396 & \\
& 5\% level & -2.913549 & \\
& 10\% level & -2.594521 & \\
\hline \hline
\end{tabular}

*MacKinnon (1996) one-sided p-values.

Augmented Dickey-Fuller Test Equation

Dependent Variable: D(EXR,2)

Method: Least Squares

Date: 09/09/20 Time: 17:49

Sample (adjusted): 19622018

Included observations: 57 after adjustments

\begin{tabular}{|c|c|c|c|c|}
\hline Variable & Coefficient & Std. Error & t-Statistic & Prob. \\
\hline $\mathrm{D}(\mathrm{EXR}(-1))$ & -0.518592 & 0.105408 & -4.919846 & 0.0000 \\
\hline \multirow[t]{2}{*}{$\mathrm{C}$} & -2.3 & 1.820000 & -1.273146 & 0.2083 \\
\hline & & & dependent & \\
\hline R-squared & \multicolumn{2}{|l|}{0.305598 var } & & 0.952421 \\
\hline \multirow[t]{2}{*}{ Adjusted R-squared } & \multirow[t]{2}{*}{0.292973} & \multicolumn{2}{|c|}{ S.D. dependent var } & \multirow[t]{2}{*}{15.21310} \\
\hline & & \multicolumn{2}{|c|}{ Akaike info } & \\
\hline S.E. of regression & \multicolumn{3}{|c|}{12.79192 criterion } & 7.969962 \\
\hline Sum squared resid & 8999.824 & Schwarz & criterion & \multirow[t]{2}{*}{8.041648} \\
\hline & & \multicolumn{2}{|c|}{$\begin{array}{l}\text { Schwarz criterion } \\
\text { Hannan-Quinn }\end{array}$} & \\
\hline Log likelihood & \multicolumn{3}{|c|}{-225.1439 criter. } & 7.99782 \\
\hline F-statistic & 24.20489 & \multirow{2}{*}{\multicolumn{2}{|c|}{ Durbin-Watson stat }} & 2.308680 \\
\hline Prob(F-statistic) & 0.000008 & & & \\
\hline
\end{tabular}

Dependent Variable: GDPPCG 
Method: Least Squares

Date: 09/12/20 Time: 10:39

Sample (adjusted): 19612018

Included observations: 56 after adjustments

Convergence achieved after 7 iterations

\begin{tabular}{|c|c|c|c|c|}
\hline Variable & Coefficient $\mathrm{St}$ & Std. Error & t-Statistic & Prob. \\
\hline $\mathrm{C}$ & 2.136217 & 2.292989 & 0.931630 & 0.3559 \\
\hline REMITR & 2.289418 & 3.212333 & -0.712696 & 0.0003 \\
\hline INFR & -0.062754 & 0.068530 & -0.915714 & 0.0041 \\
\hline EXR & 0.036880 & 0.041841 & 0.881417 & 0.0022 \\
\hline $\operatorname{AR}(1)$ & 0.435419 & 0.125758 & 3.462346 & 0.0011 \\
\hline \multicolumn{5}{|c|}{ Mean dependent } \\
\hline R-squared & \multicolumn{3}{|l|}{$0.714237 \mathrm{var}$} & 0.986775 \\
\hline \multirow[t]{2}{*}{ Adjusted R-squared } & 0.652609 & \multicolumn{2}{|c|}{ S.D. dependent var } & \multirow[t]{2}{*}{6.951634} \\
\hline & \multicolumn{3}{|c|}{ Akaike info } & \\
\hline S.E. of regression & \multicolumn{3}{|c|}{6.399248 criterion } & 6.635283 \\
\hline Sum squared resid & 2088.469 & \multirow{2}{*}{\multicolumn{2}{|c|}{$\begin{array}{l}\text { Schwarz criterion } \\
\text { Hannan-Quinn }\end{array}$}} & \multirow[t]{2}{*}{6.816118} \\
\hline & & & & \\
\hline Log likelihood & \multicolumn{3}{|l|}{-180.7879 criter. } & \multirow{3}{*}{$\begin{array}{l}6.705393 \\
1.836336\end{array}$} \\
\hline F-statistic & 3.476268 & \multirow{2}{*}{\multicolumn{2}{|c|}{ Durbin-Watson stat }} & \\
\hline Prob(F-statistic) & 0.013816 & & & \\
\hline Inverted AR Roots & .44 & & & \\
\hline
\end{tabular}

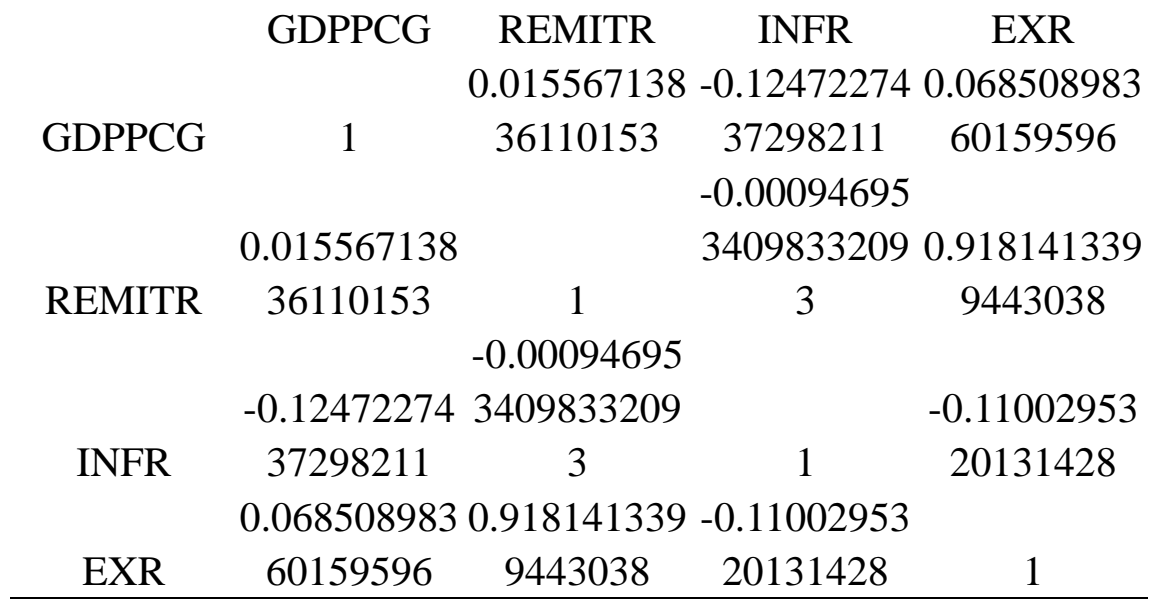

Pairwise Granger Causality Tests

Date: 09/10/20 Time: 20:11 
Sample: 19602018

Lags: 2

\begin{tabular}{lccc}
\hline \hline Null Hypothesis: & Obs & F-Statistic & Prob. \\
\hline \hline $\begin{array}{l}\text { REMITR does not Granger Cause } \\
\text { GDPPCG }\end{array}$ & 57 & $\begin{array}{l}0.24157 \\
0.15736\end{array}$ & 0.7003 \\
GDPPCG does not Granger Cause REMITR & & 0.0040 \\
\hline \hline INFR does not Granger Cause GDPPCG & 54 & 0.75160 & 0.0000 \\
GDPPCG does not Granger Cause INFR & & 0.30886 & 0.0050 \\
\hline \hline EXR does not Granger Cause GDPPCG & 57 & 0.28450 & 0.0006 \\
GDPPCG does not Granger Cause EXR & & 0.07487 & 0.000 \\
\hline \hline INFR does not Granger Cause REMITR & 54 & 0.66742 & 0.0001 \\
REMITR does not Granger Cause INFR & & 1.19441 & 0.0005 \\
\hline \hline EXR does not Granger Cause REMITR & 57 & 2.33743 & 0.0001 \\
REMITR does not Granger Cause EXR & & 3.54907 & 0.0359 \\
\hline \hline EXR does not Granger Cause INFR & 54 & 0.28418 & 0.7539 \\
INFR does not Granger Cause EXR & & 0.67349 & 0.5146 \\
\hline \hline
\end{tabular}

\section{Copyright Disclaimer}

Copyright for this article is retained by the author(s), with first publication rights granted to the journal.

This is an open-access article distributed under the terms and conditions of the Creative Commons Attribution license (http://creativecommons.org/licenses/by/4.0/). 